\title{
Review of the Hydrotaea parva and Hydrotaea glabricula groups (Diptera: Muscidae)
}

\author{
Обзор видов групп Hydrotaea parva и Hydrotaea glabricula \\ (Diptera: Muscidae)
}

\author{
Nikita E. Vikhrev \\ H.E. Вихрев
}

\begin{abstract}
Zoological Museum of Moscow University, Bolshaya Nikitskaya 6, Moscow 125009, Russia. E-mail: nikita6510@ya.ru Зоологический музей, Московский государственный университет им. М.В. Ломоносова, Большая Никитская ул., 6, Москва 125009 , Россия.
\end{abstract}

KEY WORDS: Diptera, Muscidae, Hydrotaea parva group, Hydrotaea glabricula group, new species, new synonymies, taxonomy.

КЛЮЧЕВЫЕ СЛОВА: Diptera, Muscidae, группа Hydrotaea parva, группа Hydrotaea glabricula, новые виды, новые синонимы, систематика.

ABSTRACT. The fauna of the Hydrotaea parva group and the here proposed Hydrotaea glabricula group is considered. Identification keys for the Eurasian and Afrotropical faunas of the Hydrotaea glabricula group and for the Palaearctic and Eurasian faunas of the Hydrotaea parva group are given. Five new species $H$. semiflava sp.n. (from Sri Lanka), H. elephans sp.n., H. ozerovi sp.n., H. portschinskyi sp.n. and $H$. stackelbergi sp.n. (all from Thailand) and one subspecies $H$. polita kenyana ssp.n. (from Kenya) are described. Two new synonymies are proposed: $H y$ drotaea atrisquama Ringdahl, $1925=$ Hydrotaea multipilosa Shinonaga et Kano, 1983, syn.n. and Hydrotaea parva Meade, $1889=$ Hydrotaea exigua Shinonaga et Kano, 1983, syn.n.

РЕЗЮМЕ. Рассмотренна фауна групп видов Hydrotaea parva и Hydrotaea glabricula (последняя предложена в настоящей работе). Даны определительные ключи для евразийской и афротропической фаун группы Hydrotaea glabricula и для палеарктической и евразийской фаун группы Hydrotaea parva. Описано 5 новых видов: H. semiflava sp.n. (Шри Ланка), H. elephans sp.n., H. ozerovi sp.n., $H$. portschinskyi sp.n. и H. stackelbergi sp.n. (все Таиланд) и 1 подвид: H. polita kenyana ssp.n. (Кения). Предложено 2 новых синонима: Hydrotaea atrisquama Ringdahl, 1925 = Hydrotaea multipilosa Shinonaga et Kano, 1983, syn.n.; Hydrotaea parva Meade, $1889=$ Hydrotaea exigua Shinonaga et Kano, 1983, syn.n.

\section{Introduction}

There are about 120 valid species of Hydrotaea Robineau-Desvoidy, 1830 s. str. worldwide. As other
Azeliini, the genus Hydrotaea has the center of biodiversity in the temperate zone of Eurasia. About 70-75 species (almost $2 / 3$ of total amount) are Palaearctic (including several Holarctic species and a rich fauna of Hydrotaea recorded from S China, N India, N Myanmar, N Vietnam). In the Afrotropical and Oriental regions 15-20 species are known in each; 10-12 species are American (excluding Holarctic ones).

Of the Palaearctic species, there are 3 with body length $4 \mathrm{~mm}$ and less: Hydrotaea parva Meade, 1889; $H$. atrisquama Ringdahl, 1925 and $H$. glabricula Fallén, 1825, the former 2 species are closely related and form the Hydrotaea parva species-group proposed by Ringdahl [1925] and used by Hennig [1962]. H. glabricula has no related species in the Palaearctic region but it has several related Paleotropical species, so the $H$. glabricula group is proposed in present work. In the Oriental region, there are also several more species which should be uncluded in the H. parva group.

Small size is not a bad diagnostic character to distinguish both considered species-groups from other species of Hydrotaea, but in some cases the overlapping takes place. For example, $H$. parva has body length 3.3-4.0 mm, Hydrotaea armipes Fallén, 1825 - 3.5$6.0 \mathrm{~mm}$ [Gregor et al., 2002]. Fortunately another trait may serve as a good character of the Hydrotaea parva and $H$. glabricula groups: ac setae rather strong, placed in 2 rows, without any additional hairs between rows. The following key defines the borders of the considered groups and separetes them from the rest of $\mathrm{Hy}$ drotaea:

1. $a c$ setae rather strong, in 2 rows and without any additional hairs between rows. Body length less than $4 \mathrm{~mm}$. (Either $t 2$ with $a d$ or body length less than $3 \mathrm{~mm}$.) ..... 2 - ac setae or setulae in 3 or more rows. Body length more than $4 \mathrm{~mm}$ other species of Hydrotaea 
2. $t 2$ without $a d$. Body length less than $3 \mathrm{~mm}$, glossy black. +: frontal triangle glossy and remarkably wide, with convex sides, so interfrontalia are almost reduced; interfrontal setae situated on outer margines of frontal triangle and widely separated as shown on Fig. 1. Attracted to animal or human body ............... H. glabricula group

- $t 2$ with $1 \mathrm{ad}$. Body length 3-4 mm, with dictinct, though usually tint dusting. + : frontal triangle at least partly math, not widened, interfrontalia are not reduced, interfrontal setae not widely separated ( Fig. 2). Attracted to herbivorous dung..... H. parva group

These groups of Hydrotaea are unknown from Australia and from the New World as well, so the present paper deals with the entire presently known world fauna of the $H$. parva and $H$. glabricula groups. To make the identification keys easier to use, the paper is divided onto 4 Parts: Eurasian H. glabricula groups (1.1); Afrotropical $H$. glabricula groups (1.2); Palaearctic $H$. parva group (2.1) and Eurasian H. parva group (2.2).

\section{Material and methods}

The majority of the specimens studied are in the Zoological Museum of Moscow University, Russia (ZMUM), in this case specimen attribution is not indicated in text. Holotypes of all species described in present paper are in the ZMUM. Collection of Museum für Naturkunde, Humboldt-Universität zu Berlin, Germany is abbreviated as ZMHU.

Localities (where possible) are given as follows: country, region, locality, geographical coordinates (in the Decimal Degrees format).

The following abbreviations for morphological structures are used: $f 1, t 1, f 2, t 2, f 3, t 3=$ fore-, mid-, hind - femur or tibia; $a c=$ acrostichal setae; $d c=$ dorsocentral setae; $a, p, d, v=$ anterior, posterior, dorsal, ventral seta(e); prst — presutural, post — postsutural. The abbreviation for the tarsi as tar followed by a pair of digits separated by a hyphen was proposed by Vikhrev [2011]: the first digit (1 to 3) gives the leg number and the second digit ( 1 to 5 ) the number of the tarsal segment. For example, tar $2-4=4$ th segment of mid tarsus; $\operatorname{tar} 3-1=$ hind basitarsus.

The illustrations are original unless otherwise indicated.

\section{Taxonomy}

\section{Hydrotaea glabricula species-group}

Species of the $H$. glabricula group have remarkably small body size $2.5-3.0 \mathrm{~mm}$. Females are easily distinguished by the frontal triangle glossy and remarkably wide, with convex sides, so the interfrontalia are reduced to a pair of anteriorly converging narrow strips; interfrontal setae are situated on outer margines of the frontal triangle and are widely separated as shown on Fig. 1. Males: eyes bare, contiguous. Fronto-orbital plates glossy, narrow. Antenna short, arista almost bare.
Thorax shining black or with a very slight grey dusting, $a c$ rather strong in 2 rows, $2+4 d c$, meron, katepimeron and notopleuron bare. Legs: $f 1$ with two typical ventral hooks at apex; $t 1$ without setae; $f 2$ with a complete row of $p$ setulae and $2 p d$ preapicals, $v$ surface with 2-3 spines at basal third; $t 3$ with 1-2 av and 1 ad below middle, $p d$ absent or shorter than half width of tibia; tarsi not modified.

According to Gregor et al. [2002] adults of $H$. glabricula are attracted by decaying meat. I had never seen any species of the $H$. glabricula group on carrion, but always observed both sexes were attracted by human body, especially legs.

\subsection{Eurasian fauna of the $H$. glabricula group}

Three species are known from Eurasia and considered below. Hydrotaea polita Emden, 1943, described from the Afrotropical region, was listed by Pont [1991] for Saudi Arabia based on a female specimen. Formally it is a Palaearctic record but I do not consider $H$. polita here because in Emden's description I had not found any difference of $H$. polita from $H$. glabricula in the female sex.

\section{Hydrotaea glabricula Fallén, 1825}

Hydrotaea glabricula Fallén, 1825. Type locality: presumably Skane, Sweden [Pont, 1986].

Hydrotaea nitida Robineau-Desvoidy, 1830. Type locality: France [Pont, 1986].

Hydrotaea atrata Robineau-Desvoidy, 1830. Type locality: France [Pont, 1986].

Hydrotaea minima Rondani, 1871. Type locality: "Alp forest" [Pont, 1986].

MATERIAL EXAMINED. RUSSIA: Bashkortostan reg., Abzakovo env., $53.8^{\circ} \mathrm{N} 58.6^{\circ} \mathrm{E}, 5-8$.VIII.2008, K. Tomkovich, 1 웅 Khakassia reg., Shira distr., Maloe Spirinskoe Lake (freshwater), $54.422^{\circ} \mathrm{N} 90.147^{\circ} \mathrm{E}, 26 . \mathrm{VI} .2011, \mathrm{~K}$. Tomkovich, 4 oo; TURKEY: Konya prov., Kurucay, [37.22 ${ }^{\circ} \mathrm{N} 32.01^{\circ} \mathrm{E}$ ], $1700 \mathrm{~m}$ asl, 27.IX.2007, N. Vikhrev, $1 \mathrm{O}^{7}$; Antalya prov., Side, sand dune, $36.77^{\circ} \mathrm{N} 31.40^{\circ} \mathrm{E}$, 2.IV.2008, A. Ozerov, 1 व'.

DISTRIBUTION. The warm and temperate zones of the Palaearctic from W Europe to Japan [Pont, 1986]; in China: Liaoning, Shaanxi and Shanxi provinces [Xue \& Chao, 1998].

Hydrotaea nigrirensis Shinonaga et Tewari, 2008

Hydrotaea nigrirensis Shinonaga et Tewari, 2008. Type locality: India: Kerala and Tamil Nadu states

MATERIAL EXAMINED. CAMBODIA: Kep prov., Kep, $10.5^{\circ} \mathrm{N} 104.3^{\circ} \mathrm{E}$, attracted by human body, 5-7.12.2010, N. Vikhrev, $24 \mathrm{O}^{7} \mathrm{O}^{7}, 15$ 우; INDIA, Orissa st., Daspalla env., $20.38^{\circ} \mathrm{N} 84.77^{\circ} \mathrm{E}$, 17-25.I.2014, K. Tomkovich, 1 +; THAILAND: Chiang Mai prov., $19.28^{\circ} \mathrm{N} 98.61^{\circ} \mathrm{E} .1350 \mathrm{~m}$ asl, attracted on human body, 1518.XI.2010, N. Vikhrev, $2 O^{7} \sigma^{7}, 8$ 웅.

DISTRIBUTION. Oriental: India: Kerala, Tamil Nadu and Orissa states; Thailand, Chiang Mai prov.; Cambodia, Kep prov.

REMARKS. In their diagnosis ("remarks") Shinonaga and Tewari [2008] had not compared H. nigrirensis with a closely related $H$. glabricula, but compared it with $H$. atrisquama (and because of the synonymy of 
H. multipilosa Shinonaga et Kano, 1983 to H. atrisquama proposed in this paper, it is unclear what Shinonaga actually implied under $H$. atrisquama). In the original description of $H$. nigrirensis there are several points which contradict to my material: "notopleura hairy" and " $f 2$ with a row of long bristles on anterodorsal and anteroventral surfaces". Nevertheless I believe that the series from Cambodia and Thailand are conspecific to $H$. nigrirensis and regard the mentioned characters as description errors, actually notopleuron is bare in all other species of the $H$. glabricula group and $f 2$ has a complete $p$-row, $a$-row and 2 sharp ventral spines in basal half.

Undescribed females of $H$. nigrirensis were collected with males in Cambodia and Thailand, but I did not found in them any reliable differences from females of $H$. glabricula.

\section{Hydrotaea semiflava sp.n.}

Figs 3-4.

MATERIAL. Holotype $0^{7}$, SRI LANKA: Maravilla, $7.44^{\circ} \mathrm{N}$ $79.81^{\circ} \mathrm{E}, 26-31.12 .2012$, N. Vikhrev. Paratypes: $1 \mathrm{O}^{7}, 4$ 우, the same label.

DESCRIPTION. MALE. A dark glossy species with mostly yellow abdomen, body length: $2.5-2.9 \mathrm{~mm}$.

Head. Eyes bare, upper facets strongly enlarged. Fronto-orbital plates touch, distance between eyes equal to diameter of anterior ocellus. Fronto-orbital plates glossy, narrow; parafacials glossy, linear. Fronto-orbital plates with 2 pairs of inclinate setae near lunula. Gena and occiput matt black. Antenna short, pedicel yellowish, postpedicel black, arista almost bare, basal part of arista whitish. Palpi black.

Thorax shining black with a very slight grey dusting, ground setulae on scutum reduced. Chaetotaxy: $a c$ rather strong in 2 rows, $3+4$ pairs, without any additional hairs between rows; $2+4 d c$; katepisternal $1+1$, meron, katepimeron and notopleuron bare. Wing clear, calypters yellow, haltere yellow.

Legs black (looks yellowish in collected material). $f 1$ with two typical ventral hooks at apex. $t 1$ without setae. $f 2: p$ surface with a complete row of setulae, $a$ surface with a row of 4-5 setae in basal half, $v$ surface with 3 spines (almost $1.5 \mathrm{x}$ as long as femur width) in basal third (the first spine the shorter, the last one the stonger). $t 2$ with 2 strong $p$ setae. $f 3$ ventrally with 3-4 $a v$ near apex. $t 3$ with 1 submedian $a d, 1$ av below middle and 1 fine $d$ seta near apex, $p d$ absent or shorter than half width of tibia. Tarsi not modified.

Abdomen (Fig. 3) yellow, but tergite 4 dorsally with black triangular mark widened posteriorly, tergite 5 and sternite 5 entirely black.

FEMALE differs from male as follows: frons wide with glossy-black frontal triangle which is remarkably wide, so it is almost contiguous to fronto-orbital plates; interfrontal setae are widely spaced being placed almost at outer margins of frontal triangle; $f 1$ unmodified; $f 2$ without $p d$ row and without ventral spines; abdomen glossy black with only base yellow (Fig. 4).
ETYMOLOGY. The name refers to the partly yellow colour of body (Latin: semi = half, flava = yellow).

DIAGNOSIS. $H$. semiflava sp.n. may be reliably separated in both sexes from related species as indicated in the key below.

IDENTIFICATION KEY FOR THE HYDROTAEA GLABRICULA GROUP FOR the Palaearctic AND Oriental Regions ( $\sigma^{7} \bigcirc^{7}$ AND +9 )

1. Abdomen mainly ( $\sigma^{\top}$, Fig. 3$)$ or at least basally $(+$, Fig. 4) yellow. Pedicel yellow(ish). Haltere yellow. $O^{7}$ : Calypters whitish; $f 2$ with 3 longer ventral spines. $t 3$ with fine $d$ seta near apex and with only $1 a v$. Sri Lanka ............. semiflava sp.n.

- Abdomen black. Pedicel black. Haltere dark. $\sigma^{7}: f 2$ with 2 shorter ventral spines. $t 3$ without fine $d$ seta near apex

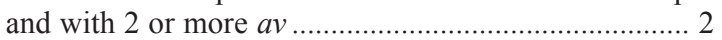

2. $O^{7}$ : Calypters whitish. Scutum and abdomen glossy. $t 3$ with a row of 3-5 fine $p v$ setulae in apical third. Palaearctic. glabricula Fallén

- $\sigma^{7}$ : Calypters dark. Scutum with slight dusting, abdomen with slight dusting and with dark median vitta on tergites $1+2$ to 4 . $t 3$ without a row of $p v$ setulae. Oriental. . nigrirensis Shinonaga et Tewari

\subsection{African fauna of the $H$. glabricula group}

Hydrotaea latitarsis Emden, 1943

Fig. 5.

Hydrotaea latitarsis Emden, 1943. Type locality: Uganda.

MATERIAL. No material seen.

DISTRIBUTION. Uganda.

REMARKS. H. latitarsis was first mentioned in the key for Afrotropical Hydrotaea by [Emden, 1943: 83], the detailed description of this species was given in his later work [Emden, 1951: 667].

\section{Hydrotaea polita polita Emden, 1943}

Hydrotaea polita Emden, 1943. Type locality: Uganda, Kampala env and Tanganyika, Kilossa [Tanzania, Kilosa, H” 6.8S 37.0E] MATERIAL. No material seen.

DISTRIBUTION. Uganda and Tanzania.

\section{Hydrotaea polita kenyana Vikhrev ssp.n.}

MATERIAL. Holotype $\sigma^{7}$, KENYA: Laikipia county, Thomson Falls env., $0.05^{\circ} \mathrm{N} 36.38^{\circ} \mathrm{E}, 2350 \mathrm{~m}$ asl, 21-30.XII.2013, N. Vikhrev. Paratypes $1 O^{7}$ and $1 \%$, the same label as holotype.

DESCRIPTION. MALE. A dark glossy species, body length: $3.1-3.5 \mathrm{~mm}$.

Head. Eyes bare, upper facets strongly enlarged. Fronto-orbital plates touching, distance between eyes equal to diameter of anterior ocellus. Fronto-orbital plates glossy, narrow; parafacials glossy, linear. Fronto-orbital plates with 2 pairs of inclinate setae near lunula. Gena and occiput subshining black. Antenna short, black, arista almost bare. Palpi black.

Thorax glossy black. Chaetotaxy: $a c$ rather strong in 2 rows, $3+4$ pairs, without any additional hairs be- 

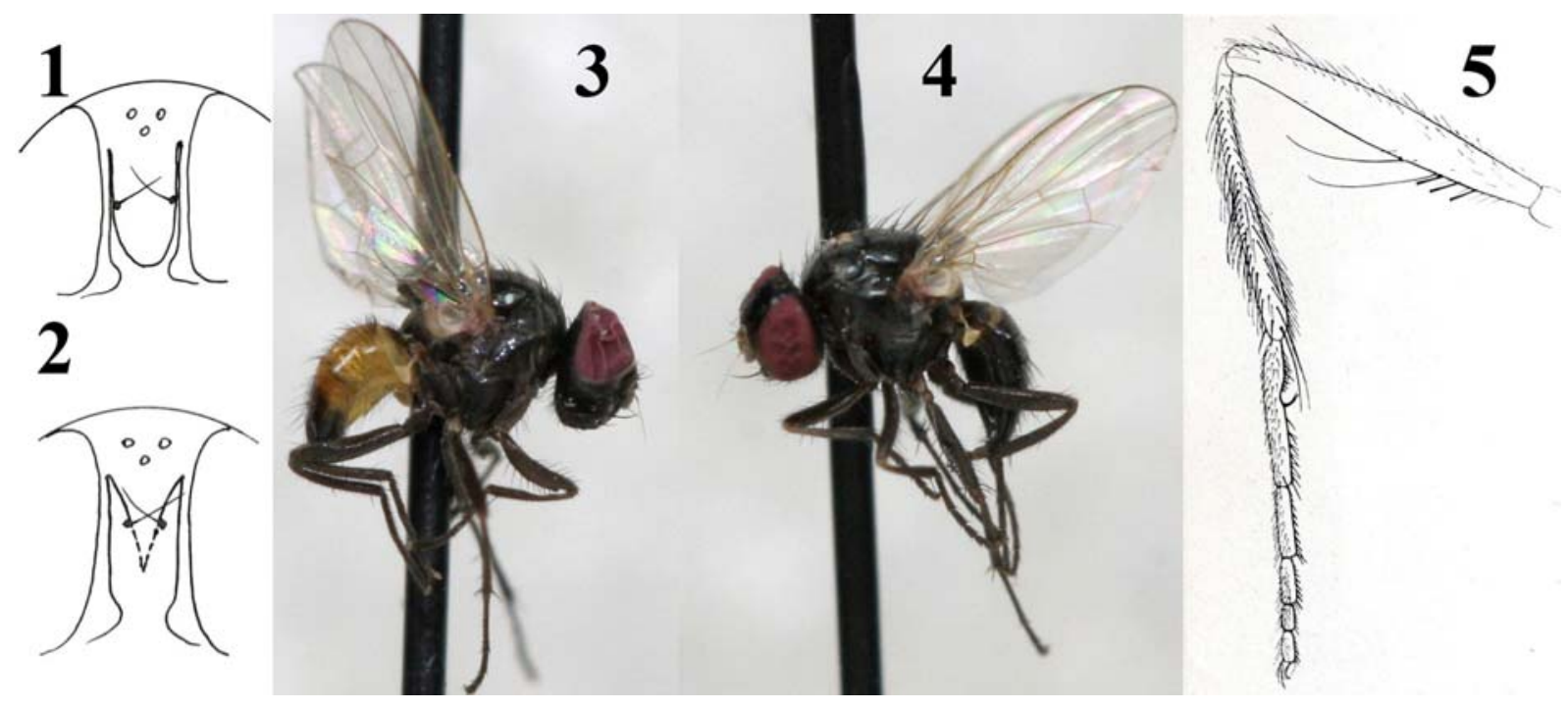

Figs 1-5. Hydrotaea glabricula group.

1-2 - female frons: $1-H$. glabricula group; $2-H$. parva group; $3-4-H$. semiflava sp.n.: $3-$ male holotype; $2-$ female paratype; 5 - H. latitarsis Emden, 1943, male mid leg (by Emden, 1951).

Рис 1-5. Группа видов Hydrotaea glabricula.

1-2 - лоб самки: 1 - группа H. glabricula; 2 - группа H. parva; 3-4 - H. semiflava sp.n.: 3 - самец (голотип); 2 - самка (паратип); 5 - H. latitarsis Emden, 1943, средняя нога самца (по Emden, 1951).

tween rows; $2+4 d c$; katepisternal $1+1$, meron, katepimeron and notopleuron bare. Wing clear, calypters and haltere dark brown.

Legs black. $f 1$ with two typical ventral hooks at apex. $t 1$ without setae. $f 2: p$ surface with a complete row of setulae and $2 p d$ preapicals, $a$ surface with a row of 4-5 setae in basal half, $v$ surface with 3 spines $(1.5$ $2 \mathrm{x}$ as long as femur width) in basal half (the first spine the shorter, the last two stonger). $t 2$ with 2 strong $p$ setae. $f 3$ ventrally: 3 long $a v$ near apex; 2 short but strong $v$ setae at base and at basal $1 / 4 ; 2$ long $(3 \mathrm{x}$ as long as femur width) $p v$ setae at 1/3 and 2/3. t3: 1 long ad setae at middle or slightly above it; 1 shorter $a v$ slightly above level of ad seta; 1 long an fine $p v$ at basal 1/3; setulae on ad surface distinctly elongated . Tarsi not modified.

Abdomen black; tergites $1+2,3$ and anterior half of tergite 4 with fine dusting and glossy median vitta; posterior half of tergite 4 and tergite 5 glossy.

FEMALE differs from male as follows: frons wide with glossy-black frontal triangle which is remarkably wide and almost contiguous to fronto-orbital plates; interfrontal setae widely spaced, placed almost at outer margins of frontal triangle; $f 1$ unmodified; $f 2$ without $p d$ row and without ventral spines; $f 3$ without $p v$ setae; $t 3$ without $p v$ seta and elongated $a d$ setulae; abdomen entirely glossy black.

ETYMOLOGY. The name indicates Kenyan origin of the type series of the new subspecies.

DIAGNOSIS. H. polita kenyana ssp.n. shares with the nominotypical subspecies $H$. p. polita $f 3$ with remarkably long sparse $p v$ setae and $t 3$ with $1 a v$ and $1 p v$ setae which placed in basal half of tibia above $a d$ seta. That is why I do not think that H. p. kenyana should be regarded as a valid species. On the other hand $H . p$. kenyana ssp.n. differs from $H$. p. polita in both sexes by dark calypteres and by the hind leg chaetotaxy in males. The distance between type localities of $H . p$. polita and H. p. kenyana ssp.n. is less than $500 \mathrm{~km}$, but the height of localities substantially differ, 600-1100 $\mathrm{m}$ asl for the first and $2350 \mathrm{~m}$ asl for the second one.

IDENTIFICATION KEY FOR THE HYDROTAEA GLABRICULA GROUP FOR THE Afrotropical REgION ( $\sigma^{\top} \sigma^{\top}$ AND ++ )

1. $\bigcirc^{7}$ : Mid leg modified (Fig. 5): $f 2$ with 2 remarkably long $v$ setae before middle; $t 2$ covered with dense and long $p$ hairs, so the two strong $p$ setae are hardly distinguishable; tar $2-1$ dilated and flattened, on $v$ surface with an excavation before middle, in which a comb of 3 stout, short, recurved setulae is placed. $f 3$ without very long $p v$ setae, $t 3$ without $p v$ in basal 1/3. + : cruciate interfrontal setae absent.... latitarsis Emden

$-O^{7}$ : Mid leg not modified as above. $f 3$ with 2 very long $p v$ setae at $1 / 3$ and $2 / 3$ of femur length from base; $t 3$ with $p v$ in basal 1/3. $O$ : cruciate interfrontal setae present ......... polita Emden 2

2 . Calypters whitish with yellowish border. $\sigma^{7}: f 3$ with 3 very long $p v$ setae at base, at $1 / 3$ and $2 / 3$ of femur length from base. Tanzania, Uganda ........ polita polita Emden - Calypters dark brown. $\sigma^{x}: f 3$ with 2 very long $p v$ setae at $1 /$ 3 and 2/3 of femur length from base; basal seta absent. Kenya ...................................... polita kenyana ssp.n.

\section{Hydrotaea parva species-group}

H. parva group is represented in the Palaearctic region by 2 species. Gregor et al. [2002] characterized $H$. parva as "not too common Eurasian species", $H$. atrisquama was a mysterious species known from Swe- 
den and Myanmar [Emden, 1965]. The material listed below shows that both species actually are not rare around horse dung on pastures. Males occasionally visit dunghills, but mostly swarm in $30-100 \mathrm{~cm}$ from dung at a height of $20-40 \mathrm{~cm}$, being hardly noticeable against a motley background of grass and soil; females usually visit dung or seat on grass around it. $H$. parva seems to be more common in the western part of Palaearctic, $H$. atrisquama in the eastern parts and is found further northerly than $H$. parva. In the Oriental region there are several described or undescribed species of the $H$. parva group, so I believe more useful first to consider two species of the Palaearctic fauna (probably present in the North of the Oriental region too) and then to consider the entire Eurasian fauna.

\subsection{Palaearctic fauna of the H. parva group}

\section{Hydrotaea atrisquama Ringdahl, 1925} Fig. 6.

Hydrotaea atrisquama Ringdahl, 1925. Type locality: Sweden, Skane, Asljunga.

Hydrotaea multipilosa Shinonaga \& Kano, 1983 - syn.n. Type locality: Japan.

MATERIAL EXAMINED. RUSSIA: Bashkortastan reg., Beloretsk env., Nura R., $54.05^{\circ} \mathrm{N} 58.27^{\circ} \mathrm{E}, 6-13$.VIII.2012, D. Gavryushin, $1 \mathrm{O}^{\top}$; Khabarovsk reg, Bychikha, $48.30^{\circ} \mathrm{N} 134.82^{\circ} \mathrm{E}, 13$.VII. 2014, horse dung, N. Vikhrev, 1 ; Khanty-Mansi reg., S-E KhantyMansiysk, 7-13.VIII.2010, $60.9^{\circ} \mathrm{N} 68.7^{\circ} \mathrm{E}, \mathrm{K}$. Tomkovich, $1 \mathrm{O}^{7}$; Magadan reg, Stekolny, $60.06^{\circ} \mathrm{N} 150.75^{\circ} \mathrm{E}, 16-18 . \mathrm{VII} .2014$, N. Vikhrev, $1 \mathrm{O}^{\text {? }}$; Primorsky Kray reg.,Ussuri NR, Komsomolskaya polyana, $43.63^{\circ} \mathrm{N} 132.29^{\circ} \mathrm{E}$, 5.VIII.2013, I. Gomyranov, $1 \mathrm{O}^{7}$; Razdolnoe env., $43.54^{\circ} \mathrm{N} 131.84^{\circ} \mathrm{E}$, horse dung, 25.VI.2014, N. Vikhrev, $4 \mathrm{O}^{7} \mathrm{O}^{7}$, 4우; Tver reg, Rzhev env, $56.21^{\circ} \mathrm{N} 34.35^{\circ} \mathrm{E}$, horse dung, 18.VIII.2014, N. Vikhrev, 1 ㅇ.

DISTRIBUTION. Sweden (type locality); Russia: European Part, Ural, W Siberia, Far East; Japan (Shinonaga [2003] as H. multipilosa): Hokkaido and Shikoku; Myanmar (NE Burma, Kambaiti) [Emden, 1965]. The record from Myanmar looked unexpectable, but with regard to the Far Eastern and Japanese records it is not too surprising. Anyway Emden's [1965] description of modified legs of the Burmese male specimen leaves no doubts in its identification.

SYNONYMY. The description and drawing of the modified hind leg of $H$. multipilosa given in Shinonaga [2003] (Fig. 6) proves that it is conspecific to H. atrisquama, so Hydrotaea atrisquama Ringdahl, $1925=$ Hydrotaea multipilosa Shinonaga \& Kano, 1983, syn.n.

\section{Hydrotaea parva Meade, 1889}

Hydrotaea parva Meade, 1889. Type locality: Great Britain, near Buckingham.

Hydrotaea exigua Shinonaga et Kano, 1983 - syn.n. Type locality: Japan.

MATERIAL EXAMINED. POLAND: Trzebiatow, $\left[54.06^{\circ} \mathrm{N}\right.$ $\left.15.26^{\circ} \mathrm{E}\right]$, 7.VIII.1917, P. Stein with Stein's identification label, 1 $0^{7}, 1$ क (ZMHU); RUSSIA: Bashkortostan reg., Abzakovo env., $53.8^{\circ} \mathrm{N} 58.6^{\circ} \mathrm{E}, 2-8$. VIII.2008, K. Tomkovich, $10^{7}, 1$ \% Khabarovsk reg, Khabarovsk, $48.6^{\circ} \mathrm{N} 135.1^{\circ} \mathrm{E}, 2-6 . \mathrm{VI} .2014$, horse dung, N. Vikhrev, $5 \mathrm{O}^{\top} \mathrm{O}^{7}$; 13.VI.2014, horse dung, N. Vikhrev, 1 $\mathrm{O}^{7}$; Khakassia reg., Shira distr., Maloe Spirinskoe freshwater Lake, $54.422^{\circ} \mathrm{N} 90.147^{\circ} \mathrm{E}, 26$. VI.2011, K. Tomkovich, $1 \mathrm{O}^{\top}$; Krasnodar reg.: Veseloe env., $43.39^{\circ} \mathrm{N} 40.00^{\circ} \mathrm{E}, 19-23 . X .2007$, N. Vikhrev, $6 \mathrm{O}^{7} \mathrm{O}^{7}$; 27.VI.2008, K. Tomkovich, $10 \mathrm{O}^{7} \mathrm{O}^{7}$; Guzeripl, $44.004^{\circ} \mathrm{N}$ $40.134^{\circ} \mathrm{E}, 700 \mathrm{~m}$ a.s.1., horse dung, 11-14.VI.2012, N. Vikhrev, 3 $\sigma^{7} \sigma^{7}$; Khosta env., $43.52^{\circ} \mathrm{N} 39.87^{\circ} \mathrm{E}, 2 . \mathrm{V} .2011$, N. Vikhrev, 10 $0^{7} 0^{\prime \prime}, 3$ 우; Varenikovskaya env., $45.083^{\circ} \mathrm{N} 37.586^{\circ} \mathrm{E}, 27 . \mathrm{IV} .2014$, N. Vikhrev, $1 \mathrm{O}^{7}$; Moscow reg., Sergiev Posad env., $56.331^{\circ} \mathrm{N}$ $38.040^{\circ}$ E, horse dung, 27.VI.2012, N. Vikhrev, $10^{\top}, 1$; ; Primorsky Kray reg., Khanka Lake, $45.06^{\circ} \mathrm{N} 131.99^{\circ} \mathrm{E}, 15-19 . \mathrm{VI} .2014$, N. Vikhrev, $2 \mathrm{O}^{\top} \mathrm{O}^{\top}$; Razdolnoe env., $43.54^{\circ} \mathrm{N} 131.84^{\circ} \mathrm{E}, 25 . \mathrm{VI} .2014$, horse dung, N. Vikhrev, $10^{7}, 1$; Stavropol reg., Stavropol env., $44.805^{\circ} \mathrm{N} 41.858^{\circ} \mathrm{E}$, horse dung, 4.V.2013, N. Vikhrev, 1 \%; Tver reg., Rzhev env., $56.21^{\circ} \mathrm{N} 34.36^{\circ} \mathrm{E}$, horse dung, 22.VI.2012, N. Vikhrev, $1 \sigma^{7}, 56.21^{\circ} \mathrm{N} 34.35^{\circ} \mathrm{E}$, horse dung, 18.VIII.2014, N. Vikhrev, $60^{7} 0^{7}, 2$ Oᄋ; SERBIA: Crni Vrh env., $43.407^{\circ} \mathrm{N} 22.587^{\circ} \mathrm{E}$, $800 \mathrm{~m}$ a.s.1., 16-22.IX.2014, N. Vikhrev, $11 \mathrm{O}^{T} \mathrm{O}^{T}, 4$ +क्ष; Surèin env., $44.78^{\circ} \mathrm{N} 20.25^{\circ} \mathrm{E}, 14 . \mathrm{IX} .2014$, N. Vikhrev, 1 ㅇ.

DISTRIBUTION. Palaearctic from W Europe to Japan; in China known from Gansu, Inner Mongolia and Xinjiang provinces [Xue, Chao, 1998].

SYNONYMY. According to Shinonaga [2003] $H$. parva has $f 2$ "with 2 strong erect straight blunt bristles on ventral surface", whereas $H$. exigua has $f 2$ "with 3 (1 strong, 2 small) erect straight blunt bristles on ventral surface". In Hennig's [1962: 737] opinion, which I agree, $H$. parva has $f 2$ with 2(3) such bristles, so I see no reason why to regard $H$. exigua as a valid species and propose that Hydrotaea parva Meade, $1889=$ Hydrotaea exigua Shinonaga et Kano, 1983, syn.n.

IDENTIFICATION KEY FOR THE HYDROTAEA PARVA GROUP FOR the Palaearctic Region

$\sigma^{7} \sigma^{\top}$

- t3 with 3-4av, $1 a d, 1 p d, 1$ long $p v$ in basal $1 / 3$, without long $v$ setae. $f 3$ with 2-3 av near apex, in basal $2 / 3$ simple. Mid tarsus unmodified. $f 2$ with 2(3) ventral spines at basal 1/4. Calypters whitish ................ parva Meade

- $t 3$ without $a v, p v$ or $p d$, with $1 a d$, about 4 long downward curved $v$ setae around and 2-4 shorter $v$ setulae middle (Fig. 6). $f 3$ with 1 av near apex, in basal 2/3 modified as in Fig. 6. $\operatorname{tar} 2-3$ to $\operatorname{tar} 2-5$ dilated and with elongated $v$ hairs. $f 2$ with 5 widely spaced ventral spines: 3 in basal half and 2 in apical half. Calypters dark atrisquama Ringdahl

- $t 3$ with 2-3 av, f2 with 2 strong ventral setae at base; fronto-orbital plates glossy, frontal triangle glossy in basal part .............................................. parva Meade

- t3 with 1 av, $f 2$ without strong ventral spines at base; fronto-orbital plates glossy only at level of lunula, frontal triangle math ........................... atrisquama Ringdahl

\subsection{Eurasian fauna of the H. parva group}

I remind that the main diagnostic criteria of the $H$. parva group are as follows: presence of $1 \mathrm{ad}$ setae on t2 (1); the small (about $4 \mathrm{~mm}$ ) body size (2); $a c$ setae strong, in 2 rows without fine setulae between rows (3).

Emden [1965] listed a single Oriental species from the $H$. parva group, Palaearctic $H$. atrisquama. It is not easy to give a sufficient review of the afterwards described Oriental species of this group based on available descriptions and keys from Chinese and Japanese authors. For example, if detailed description of acros- 
tichal setae/setulae is not given, but indicated that " $a c$ $2+5$ " for small-sized Hydrotaea, that probably means that $a c$ setae are strong and sparse as should be in the $H$. parva group. I found 4 species fitting mentioned criteria:

Hydrotaea tamirensis Shinonaga et Tewari, 2008, type locality: India, Nilgiri Hills, 700-900 m asl, the border between Kartanaka and Tamil Nadu states.

Hydrotaea longiseta Feng et Feng, 1997, type locality: China, Sichuan prov., Erlangshan [H'29.8N 102.2E]

Hydrotaea muricilies Wu, Fang et Fan, 1988, type locality: China, Shaanxi prov., Huanglong [H"36N $110 \mathrm{E}]$

Hydrotaea rotundentis Shinonaga, 1999, type locality: Vietnam, Lai Chau prov., Fansipan Mt. [22.32N 103.80E]

$H$. rotundentis was described by asingle male from Fansipan Mt., but I have series of topotypes. H. rotundentis is a recognizable species though several important characters are missed in the description, the most important one is the actual presence of $a d$ seta on $t 2$, although it is short and not very conspicuous on the background of a row of elongated $a$ setulae. This and other characters are specified in the "descriptive notes" to $H$. rotundentis.

H. tamirensis has $t 2$ with $1 \mathrm{ad}$ and $2 p$ setae; " $a c$ $2+5$ "; body size $3.8-5.0 \mathrm{~mm}$ and I believe it is from the $H$. parva group. Other useful information from the original description is: squamae brown; $f 2$ with 2 strong spine-like bristles on basal half of ventral surface; $t 3$ with small $p d, 1 a d, 2 a v$. Description of hind femur is not satisfactory: " $f 3$ with a row of long bristles on $a d$ and $a v$ surfaces", while the drawing of $f 3$ shows dense $a v$ to $p v$ setae in basal half and totally bare apical half which does not fit the $f 3$ description [Shinonaga and Tewari, 2008: 210-211 and Fig. 6] (see Fig. 7 of present paper). In their diagnosis ("remarks") Shinonaga and Tewari [2008] compared $H$. tamirensis with $H$. atrisquama, but it is unclear what they understood under $H$. atrisquama as follows from synonymy to $H$. atrisquama proposed in present paper. The identification key is not given.

In case of $H$. longiseta and $H$. muricilies only identification key [Xue et al., 2007: 279, couplet 34] is available, which is cited below:

"34. Mid femur with $2 a$ setae in distal half, with a row of thick and blunt $a v$, and on middle section with a cluster of some 7-8 short spines; hind tibia with an $a d$ row, and with $2 p v$ only on middle section, the longer of the two equal to or longer than half the length of the tibia ......... Hydrotaea (s. str.) longiseta Feng \& Feng

- Mid femur with a row of some 5-6 irregular spine-like setae; mid tibia with $5 p$; fore femur with 11-12 strong setae in distal half of ventral surface, and in distal half with a row of thick and blunt $a v$; hind tibia with $4 a d$ and $4 p v$ Hydrotaea (s. str.) muricilies Wu, Fang \& Fan"

In a monograph on flies of China [Xue, Chao, 1998] $H$. longiseta is not mentioned, but the drawings of femora of $H$. muricilies are given [Xue, Chao, 1998: 899, Figs 2083 E, F, G].
As shown on Figs 7 and 8 of present paper H. tamirensis, $H$. muricilies and probably $H$. longiseta (as the differences between $H$. longiseta and $H$. muricilies given in the key by Xue et al. [2007] concern mid leg only) have resembling and unusual chaetotaxy of $f 3$ with dense ventral setae in basal half and rather bare apical half.

Four species belonging to the $H$. parva group and described below substantially differ from these 3 unclear species. All newly described Hydrotaea were collected in South Thailand, Phang Nga province, around Khao Lak, in several sites where elephant riding for tourists is organized. In most cases these sites are secondary forest or abandoned Hevea plantations, although the primary forest is also present around Khao Lak. Males of Hydrotaea were mostly collected on vegetation along elephant trails with a trend to concentrate close to walking or grazing animals. I found it difficult to attribute the collected females, so only males are included in the type series and only males are considered in the key below.

\section{Hydrotaea rotundentis Shinonaga, 1999}

Figs 9-11.

Hydrotaea rotundentis Shinonaga, 1999. Type locality: Vietnam, Fansipan Mt.

MATERIAL EXAMINED. THAILAND: Chantaburi prov., Khao Khitchakut NP env., $12.82^{\circ} \mathrm{N} 102.13^{\circ} \mathrm{E}, 1-4 . X I .2009$, N. Vikhrev, $1 \sigma^{7}$; VIETNAM: Lai Chau prov., Sa Pa env., $22.37^{\circ} \mathrm{N}$ $103.76^{\circ} \mathrm{E}, 1800 \mathrm{~m}$ a.s.1., 25-26.V.2014, A. Ozerov, $2 \mathrm{O}^{\top} \mathrm{\sigma}^{\mathrm{T}}, 22.38^{\circ} \mathrm{N}$ $103.79^{\circ} \mathrm{E}, 1700 \mathrm{~m}$ a.s.1., 25.V.2014, D. Gavryushin, $5 \sigma^{7} \sigma^{7}$.

DISTRIBUTION. Vietnam and Thailand.

DESCRIPTIVE NOTES. Male: body length 3.9$4.3 \mathrm{~mm}$. Scutum subshining black, with only trace of brownish dusting on posterior part. ac $3+4$ rather strong, without additional hairs between rows. Notopleuron bare. Calypters dark brown. $f 1$ with two typical ventral hooks at apex, but the posterior hook is rounded in posterolateral view, pinhead-shaped (Fig. 9). $f 2$ with a complete row of fine $p$ setae; in basal half with: a row of $a$ setae, 2 long $v$ spines; a row of about 9 shorter $p v$ spines; $f 2$ becomes thinner in apical 1/3 (Fig. 10). $t 2: 2$ $p$; in apical $2 / 3$ with a row of elongated $a$ setulae; in apical $1 / 3$ with 1 short $a d$ hardly conspicuous on background of of elongated $a$ setulae (Fig. 11). tar2-3 and tar 2-4 with elongated ventral setulae (Fig. 11) and widened. $f 3$ : with a complete sparse row of 8-10 long (2-3x femur width) $a v$ setae; 1 long $p v$ at 2/3. t3: $4 a v$ and $5 p v$ in middle part; $1 \mathrm{ad} ; p d$ weak and short.

VARIABILITY. The single male from Central Thailand differs form Vietnamese specimens by having setulae in $a$ row on $t 2$ shorter and less conspicuous and tar2-3 less distinctly widened.

\section{Hydrotaea elephans sp.n.}

Fig. 12.

MATERIAL. Holotype $\sigma^{7}$, THAILAND: Phang $\boldsymbol{N g} \boldsymbol{a}$ prov., Khao Lak env., elephant camp, $8.760^{\circ} \mathrm{N} 98.284^{\circ} \mathrm{E}, 16-21 . X I I .2009$, N. Vikhrev. Paratypes: $28 \sigma^{7} \sigma^{7}$ with the same label as holotype; 3 $\sigma^{\top} \sigma^{7}$ THAILAND: Phang Nga prov., Khao Lak env., elephant camp, $8.616^{\circ} \mathrm{N} 98.245^{\circ} \mathrm{E}, 14-17 . X I I .2009$, N. Vikhrev; $1 \sigma^{\top}$, THAI- 


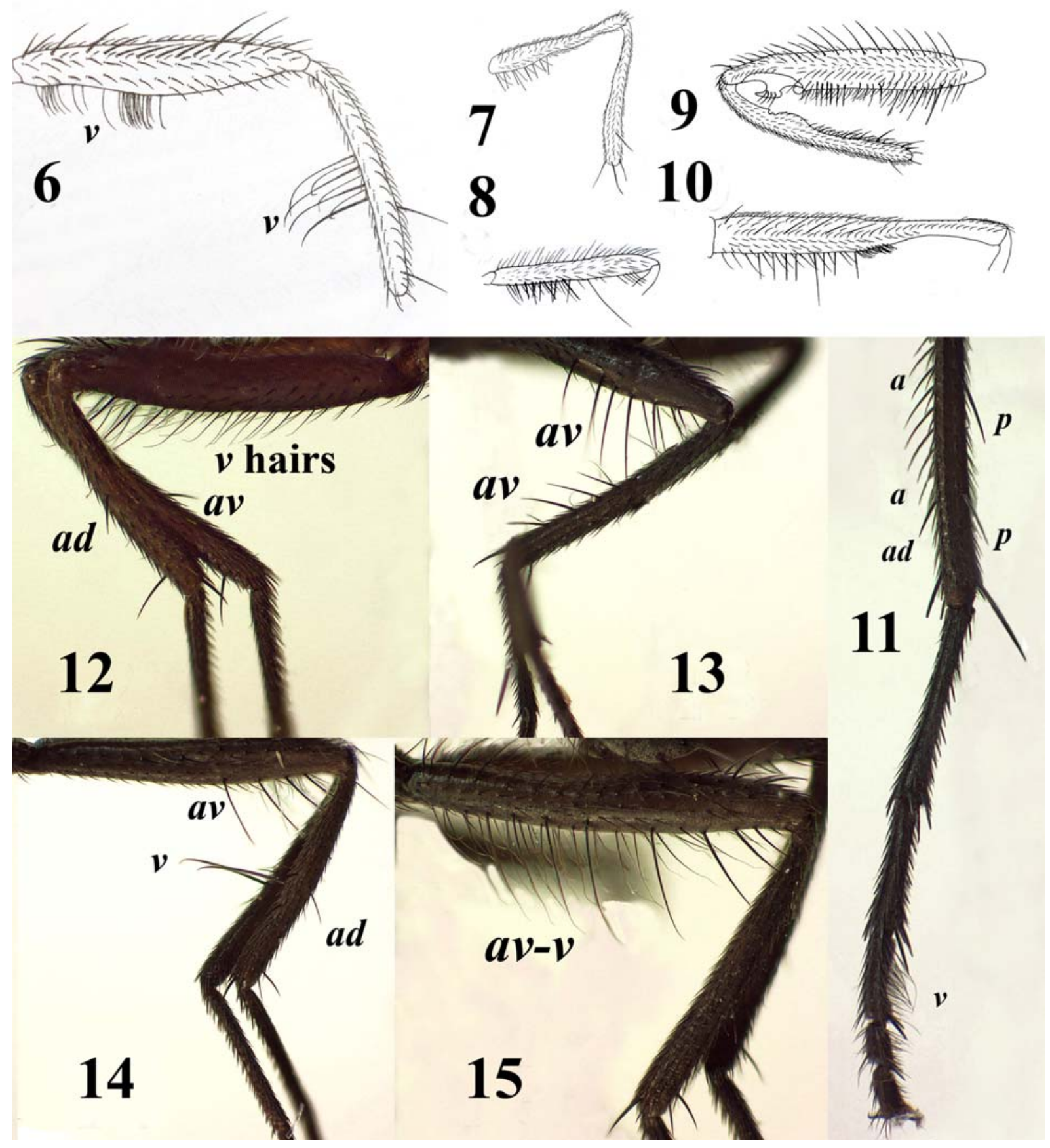

Figs 6-15. Hydrotaea parva group.

6 - H. atrisquama Ringdahl, 1925, hind leg (by Shinonaga, 2003 as H. multipilosa); 7 - H. tamirensis Shinonaga et Tewari, 2008 (by Shinonaga \& Tewari, 2008); 8 - H. muricilies Wu, Fang et Fan, 1988, hind leg (by Xue \& Chao, 1998); 9-11 - H. rotundentis Shinonaga, 1999: 9 - fore leg; 10 - mid leg (by Shinonaga \& Thinh, 1999); 11 - mid leg; 12-15 - male hind leg: 12 — H. elephans sp.n.; $13-H$. ozerovi sp.n.; $14-H$. portschinskyi sp.n.; $15-H$. stackelbergi sp.n.

Abbreviations for seta(e) or hairs position: $a$ - anterior, $v$ - ventral, $p$ - posterior, $a v$ - anteroventral, $a d$ - anterodorsal.

Рис 6-15. Группа видов Hydrotaea parva.

6 - H. atrisquama Ringdahl, 1925, задняя нога (по Shinonaga, 2003 как H. multipilosa); 7 - H. tamirensis Shinonaga et Tewari, 2008 (по Shinonaga \& Tewari, 2008); 8 - H. muricilies Wu, Fang et Fan, 1988, задняя нога (по Xие \& Chao, 1998); 9-11 - H. rotundentis Shinonaga, 1999: 9 - передняя нога; 10 - средняя нога (по Shinonaga \& Thinh, 1999); 11 - средняя нога; 12-15 — задняя нога самца: $12-$ - H. elephans sp.n.; $13-$ H. ozerovi sp.n.; $14-$ H. portschinskyi sp.n.; $15-H$. stackelbergi sp.n.

Сокращения для обозначения положения щетинок или волосков: $a-$ передняя, $v-$ вентральная, $p-$ задняя, av передневентральная, $a d$ - переднедорсальная. 
LAND: Phang $\boldsymbol{N g a}$ prov., Khao Sok NP env, $8.84^{\circ} \mathrm{N} 98.284^{\circ} \mathrm{E}$, elephant camp, 22.XII.2009, N. Vikhrev.

DESCRIPTION. MALE. A dark species, body length: $3.0-3.3 \mathrm{~mm}$.

Head. Eyes bare, upper facets strongly enlarged. Fronto-orbital plates touching, distance between eyes equal to diameter of anterior ocellus. Fronto-orbital plates glossy, narrow; parafacials glossy, linear. Fronto-orbital plates with 4 pairs of inclinate setae near lunula. Gena and occiput black. Antenna short, black, arista almost bare. Palpi black.

Thorax matt black; scutum slightly grey dusted on posterior part of postsutural area. Chaetotaxy: $a c$ rather strong in 2 rows, $3+5$ pairs, without any additional hairs between rows; $2+4 d c$; katepisternal $1+1$, meron, katepimeron and notopleuron bare. Wing evenly darkened, calypters and haltere dark brown.

Legs black. $f 1$ with two typical ventral hooks at apex. $t 1$ without setae. $f 2: p$ surface with a complete row of setulae; $a$ surface with 3 long (2-3x as long as femur width) setae in basal half; $v$ surface without spines. $t 2$ with 2 strong $p$ and 1 ad. f3: $v$ surface covered with fine short hairs which become longer (almost as long as femur width) in apical half (Fig. 12); 2-3 av and 3-4 fine $p v$ near apex. $t 3$ in submedian area with $1 a d, 1 a v$ and 1 short $p v$. Tarsi not modified.

Abdomen black; tergites $1+2$ and 3 matt black, tergites 4 and 5 slightly grey dusted and with black median vitta.

FEMALE unknown.

ETYMOLOGY. The name indicates connection of H. elephans sp.n. with elephant riding sites.

DIAGNOSIS. $H$. elephans sp.n. probably is the species misidentified by Shinonaga and Tewari [2008] as $H$. atrisquama. The most important diagnostic characters of $H$. elephans sp.n. are: $v$ surface of $f 2$ without spines; $f 3$ with $v$ surface covered with fine short hairs which become longer (almost as long as femur width) in apical half (Fig. 12) and with 2-3 $a v$ and 3-4 fine $p v$ near apex; $t 3$ in submedian area with 1 ad and $1 a v$.

\section{Hydrotaea ozerovi sp.n.}

Fig. 13.

MATERIAL. Holotype $0^{7}$, THAILAND: Phang $\mathbf{N g} \boldsymbol{a}$ prov., Khao Lak env., elephant camp, $8.760^{\circ} \mathrm{N} 98.284^{\circ} \mathrm{E}, 16-21$.XII.2009, N. Vikhrev. Paratypes: $2 \sigma^{7} \sigma^{7}$, with the same label as holotype.

DESCRIPTION. MALE. A dark species, body length: $3.2-3.6 \mathrm{~mm}$.

Head. Eyes bare, upper facets enlarged. Frontoorbital plates touching, distance between eyes equal to diameter of anterior ocellus. Fronto-orbital plates glossy, narrow; parafacials matt grey. Fronto-orbital plates with 4-5 pairs of inclinate setae. Gena and occiput black. Antenna short, black, arista almost bare. Palpi black.

Thorax black; scutum with grey dusting on posterior part of postsutural area and on notopleura and postpronotal lobe. Chaetotaxy: ac rather strong in 2 rows, 3 +5 pairs, without any additional hairs between rows; $2+4 d c$; katepisternal 1+1, meron, katepimeron and notopleuron bare. Wing slightly darkened, calypters and and haltere dark brown.
Legs black. $f 1$ with two typical ventral hooks at apex. $t 1$ without setae. $f 2: p$ surface with a complete row of setulae, $a d$ and $a v$ surfaces in basal half each with 3-4 medium long (1-1.5x as long as femur width) setae; $v$ surfaces in basal half with 2 strong spines $(1.5 \mathrm{x}$ as long as femur width); $p v$ surfaces in basal half with 5 weaker spines (as long as femur width); $f 2$ becomes thiner in apical $1 / 3 . t 2$ with 2 strong $p$ and $1 \mathrm{ad} . f 3$ with 6 long av (2.5-3x as long as femur width) setae in apical half (Fig. 13) and $4 p v(1-1.5 \mathrm{x}$ as long as femur width) in apical 1/4. $t 3$ in apical half with $4 a v(1.5 \mathrm{x}$ as long as tibia width, Fig. 13) and 3-4 fine long (2-2.5x as long as tibia width) $p v ; 1 \mathrm{ad}$ below middle and 1 short week $p d$. Tarsi not modified.

Abdomen black, thinly brownish-grey dusted, with hardly conspicuous median vitta.

FEMALE unknown.

ETYMOLOGY. H. ozerovi sp.n. is named in honour of Russian dipterologist Andrey Ozerov (Андрей Озеров), Russia, Moscow.

DIAGNOSIS. The most important diagnostic characters of $H$. ozerovi sp.n. are as follows: $f 3$ with 6 long $a v(2.5-3 \mathrm{x}$ as long as femur width) setae in apical half (Fig. 13) and $4 p v(1-1.5 \mathrm{x}$ as long as femur width) in apical $1 / 4 ; t 3$ in apical half with $4 a v(1.5 \mathrm{x}$ as long as tibia width), 3-4 fine long (2-2.5x as long as tibia width) $p v$ and $1 \mathrm{ad}$.

\section{Hydrotaea portschinskyi sp.n.}

Fig. 14.

MATERIAL. Holotype $\sigma^{r}$, THAILAND: Phang Nga prov., Khao Sok NP env., elephant camp, $8.840^{\circ} \mathrm{N} 98.474^{\circ} \mathrm{E}, 22$. XII.2009, N. Vikhrev. Paratype: $1 \sigma^{7}$, THAILAND: Phang $\boldsymbol{N g} \boldsymbol{a}$ prov., Khao Lak env., elephant camp, $8.616^{\circ} \mathrm{N} 98.245^{\circ} \mathrm{E}, 14-17 . X I I .2009$, N. Vikhrev.

DESCRIPTION. MALE. A dark species, body length: 3.4-4.0 mm.

Head. Eyes bare, upper facets enlarged. Frontoorbital plates touching, distance between eyes equal to diameter of anterior ocellus. Fronto-orbital plates glossy, narrow; parafacials matt grey. Fronto-orbital plates with 4-5 pairs of inclinate setae. Gena and occiput black. Antenna short, black, arista almost bare. Palpi black.

Thorax black; scutum thinly grey dusted on postsutural area and on notopleura and postpronotal lobe. Chaetotaxy: $a c$ rather strong in 2 rows, $2+5$ pairs, without any additional hairs between rows; $2+4 d c$; katepisternal 1+1, meron, katepimeron and notopleuron bare. Wing slightly darkened, calypters and haltere dark brown.

Legs black. $f 1$ with two typical ventral hooks at apex. $t 1$ without setae. $f 2: p$ surface with a complete row of setulae, $a d$ surface in basal half with 3-4 (1.5x as long as femur width) setae; $v$ surfaces in basal half with 4 strong spines (1.5x as long as femur width); $p v$ surfaces in basal half with 7-8 weaker spines (as long as femur width). $t 2$ with 2 strong $p$ and $1 \mathrm{ad}$. $f 3$ with 4 $a v(1.5-2 \mathrm{x}$ as long as femur width) setae in apical $1 / 3$ (Fig. 14). $t 3$ in middle with long (3-3.5x as long as tibia width) downcurved at apex ventral seta (Fig. 
14); 2-3 submedian $a v, 1 a d, 1$ distinct $p d$. Tarsi not modified.

Abdomen black, grey dusted, with black median vitta. FEMALE unknown.

ETYMOLOGY. The new species $H$. portschinskyi sp.n. is named in the memory of Russian entomologist Josef Portschinsky (Иосиф Порчинский) (18481916), the author of two species of Hydrotaea, $H$. pellicens Portschinsky, 1879 and H. meridionalis Portschinsky, 1882.

DIAGNOSIS. The most important diagnostic characters of $H$. portschinskyi sp.n. are as follows: $f 3$ with 4 $a v(1.5-2 \mathrm{x}$ as long as femur width) setae in apical $1 / 3$ (Fig. 14); $t 3$ in middle with long (3-3.5x as long as tibia width) downcurved at apex ventral seta (Fig. 14), 2-3 submedian $a v, 1$ ad, 1 distinct $p d$.

\section{Hydrotaea stackelbergi sp.n.}

Fig. 15.

MATERIAL. Holotype $\sigma^{7}$, THAILAND: Phang $\mathbf{N g a}$ prov., Khao Lak env., elephant camp, $8.760^{\circ} \mathrm{N} 98.284^{\circ} \mathrm{E}, 16-21$.XII.2009, N. Vikhrev. Paratypes: $2 O^{7} \sigma^{7}$ with the same label as holotype; 3 $\sigma^{7} \sigma^{7}$, THAILAND: Phang $\mathbf{N g} \boldsymbol{a}$ prov., Khao Lak env., elephant camp, $8.616^{\circ} \mathrm{N} 98.245^{\circ} \mathrm{E}, 14-17 . X I I .2009$, N. Vikhrev.

DESCRIPTION. MALE. A dark species, body length: $3.6-4.1 \mathrm{~mm}$.

Head. Eyes bare, upper facets enlarged. Frontoorbital plates touch, distance between eyes equal to diameter of anterior ocellus. Fronto-orbital plates glossy, narrow; parafacials matt grey. Fronto-orbital plates with 8 pairs of inclinate setae. Gena and occiput black. Antenna short, black, arista almost bare. Palpi black.

Thorax black; scutum evenly and rather densely grey dusted. Chaetotaxy: $a c$ rather strong in 2 rows, $3+$ 5-6 pairs, without any additional hairs between rows; $2+4 d c$; katepisternal $1+1$, meron, katepimeron and notopleuron bare. Wing clear, calypters whitish, haltere with brown knob.

Legs black. $f 1$ with two typical ventral hooks at apex. $t 1$ without setae. $f 2: p$ surface with a complete row of setulae; $a d$ and $a v$ surfaces in basal half each with 4-6 medium long (about as long as femur width) setae; $v$ and $p v$ surfaces in basal half with about 7 spines arranged in 2 irregular rows. $t 2$ with 2 strong $p$ and $1 \mathrm{ad} . \mathrm{f3}$ with a complete row of $12-15$ long (2x as long as femur width) $a v$ setae and with a complete row of about 15 long fine setulae on $v$ - $p v$ surfaces (Fig. 15). t3 in submedian area with $1 a d, 1 a v$ and 1 short $p v$. Tarsi not modified.

Abdomen black, distinctly grey dusted, with median vitta.

FEMALE unknown.

ETYMOLOGY. H. stackelbergi sp.n. is named in the memory of Russian dipterologist Alexander Stackelberg (Александр Штакельберг) (1897-1975).

DIAGNOSIS. The most important diagnostic characters of $H$. stackelbergi sp.n. are as follows: thorax evenly and rather densely grey dusted; calypteres whitish; $f 3$ with a complete row of $12-15$ long ( $2 x$ as long as femur width) $a v$ setae and with a complete row of about 15 long fine setulae on $v-p v$ surfaces (Fig. 15); $t 3$ in submedian area with 1 ad and $1 a v$.

IDENTIFICATION KEY FOR THE EURASIAN SPECIES OF THE HYDROTAEA PARVA GROUP $\left(\sigma^{7} \sigma^{7}\right)$

1. $f 3$ with a complete sparse row of $8-15$ long (at least $2 \mathrm{x}$ as long as femur width) $a v$ setae ..................................... 2

- $f 3$ with 6 or less long $a v$ setae confined to apical part of femur ................................................................ 3

2. $f 3$ with a complete row of $12-15$ long $(2 \mathrm{x}$ as long as femur width) $a v$ setae and with a complete row of about 15 long fine setulae on $v-p v$ surfaces (Fig. 15). $t 2$ without elongated $a$ setulae; $a d$ seta long and distinct. Mid tarsus not modified. $t 3$ with $1 a v$ and $1 a d$. $f 1$ with posterior hook not rounded, tooth-like. Calypters whitish. Scutum evenly and rather densely grey dusted stackelbergi sp.n.

- f3: with a complete sparse row of 8-10 long (2-3x femur width) $a v$ setae; 1 long $p v$ at 2/3. $t 2$ in apical $2 / 3$ with a row of elongated $a$ setulae; $a d$ seta shortened and not very conspicuous on background of of elongated $a$ setulae (Fig. 11). $\operatorname{tar} 2-3$ and $\operatorname{tar} 2-4$ with elongated ventral setulae (Fig. 11) and widened. $t 3$ with $4 \mathrm{av}, 1 \mathrm{ad}$ and 5 fine $p v$. $f 1$ with posterior hook rounded in posterolateral view, pinhead-shaped (Fig. 9). Calypters dark brown. Scutum black, with only trace of a brownish dusting on posterior part ........................... rotundentis Shinonaga

3. $t 3$ with long (at least $3 \mathrm{x}$ as long as tibia width) downcurved at apex ventral seta(e), either 1 strong or several fine setae

- $t 3$ without long downcurved at apex seta(e) in ventral position

4. $t 3$ without $a v, p v$ or $p d$, with $1 a d$ and with about 4 long downward curved $v$ setae around middle and 2-4 shorter $v$ setulae (Fig. 6). $f 3$ with 1 av near apex, in basal $2 / 3$ modified as in Fig. 6. $\operatorname{tar} 2-3$ to tar2-5 dilated and with elongated $v$-hairs. $f 2$ with 5 widely spaced ventral spines: 3 in basal half and 2 in apical half atrisquama Ringdahl

- $t 3$ in middle with 1 long and strong downcurved at apex ventral seta (Fig. 14); 2-3 submedian $a v, 1 a d, 1$ distinct $p d$. $f 3$ with 4-5 av setae in apical 1/3 (Fig. 14). Tarsi not modified. $f 2$ in basal half with 4 strong $v$ spines and 7-8 weaker $p v$ spines ........................... portschinskyi sp.n.

5. $t 3$ with 2-4 av setae and 1 or 3-4 pv. $f 2$ with 2 or $6-7$ strong ventral spines in basal half. $f 3$ in basal $2 / 3$ without a row of $v$ hairs

- $t 3$ with only $1 a v$ and without $p v \cdot f 2$ without strong ventral spines. $f 3$ in basal $2 / 3$ covered with fine $v$ hairs (Fig. 12) elephans sp.n.

6. $t 3$ in apical half with 3-4 fine $p v . f 3$ near apex apical half with 6 remarkably long $a v$ (Fig. 13). $f 2$ in basal half with 2 strong $v$ spines and 5 weaker $p v$ spines. Calypters dark ozerovi sp.n.

- t3 with $1 p v$ in basal 1/3. $f 3$ near apex with 2(3) av. $f 2$ in basal half with 2(3) strong ventral spines. Calypters whitish ..................................................... parva Meade

ACKNOWLEDGEMENTS. I thank Dr. Oleg Kosterin (Novosibirsk, Russia) for critical reading the text and valuable discussion, Dr. Andrey Ozerov (Moscow, Russia) for various support and Dr. Marina Krivosheina (Moscow, Russia) for corrections. I thank Dr. Li Shi (Hohhot, China) for her help in translating some Chinese data into English. 


\section{References}

Emden van F.I. 1943. Keys to the Muscidae of the Ethiopian Region: Phaonia-group // Annals and Magazine of Natural History. Vol.10. No.62. P.73-101.

Emden van F.I. 1951. Muscidae: C. - Scatophaginae, Anthomyiinae, Lispinae, Fanniinae and Phaoniinae // Ruwenzori Expedition 1934-35. British Museum (Natural History), London. Vol.2. No.6. P.325-710.

Emden van F.I. 1965. The fauna of India and the adjacent countries. Diptera, Vol. 7, Muscidae, Part 1. Delhi: Government of India. $647 \mathrm{pp}$.

Gregor F., Rozkošný R., Barták M., Vaňhara J. 2002. The Muscidae (Diptera) of Central Europe // Folia Facultatis Scientiarum Naturalium Universitatis Masarykianae Brunensis, Biologia 107. $280 \mathrm{pp}$.

Hennig W. 1962. Family Muscidae (Lieferung 227 and 229)// Lindner E (Hrsg.). Die Fliegen der Palaearktischen Region. Stuttgart. Bd.63b. S.698-750.

Pont A.C. 1986. Family Muscidae // Soós Á., Papp L. (eds.). Catalogue of Palaearctic Diptera. Vol.11. Akadémia Kiadó, Buda-pest. P.57-215.
Pont A.C. 1991. A review of the Fanniidae and Muscidae of the Arabian Peninsula // Fauna of Saudi Arabia. Vol.12. P.312365 .

Ringdahl O. 1925. Översikt av svenska Hydrotaea-arter (Muscidae) // Entomologisk Tidskrift. Vol.46. P.7-20.

Shinonaga S. 2003. Monograph of the Muscidae of Japan. Tokyo: Tokai University Press. 347 pp.

Shinonaga S., Tewari R.R. 2008. Record of the Muscid flies collected in India, Sri Lanka and Bangladesh (Diptera, Muscidae) // Japanese Journal of Systematic Entomology. Vol.14. No.2. P.205-251

Shinonaga S., Thinh T-H. 1999. Muscidae of Vietnam 1. Muscinae // Japanese Journal of Systematic Entomology. Vol.15. No.2. P.273-289.

Vikhrev N. 2011. Review of the Palaearctic members of the Lispe tentaculata species-group (Diptera, Muscidae): revised key, synonymy and notes on ecology // ZooKeys. Vol.84. P.59-70.

Xue W-Q., Chao C-M. 1998. Flies of China, Vol.1. Shenyang: Liaoning Science and Technology Press. 1365 pp. [in Chinese].

Xue W-Q., Wang M-F., Wang D-D. 2007. The genus Hydrotaea (Diptera: Muscidae) from China, with description of three new species // Oriental Insects. Vol.41. P.273-291. 